\title{
Correction to: Understanding university English instructors' assessment training needs in the Chinese context
}

Ling Gan ${ }^{1,2^{*}}$ and Ricky Lam ${ }^{1}$

The original article can be found online at https://doi.org/10.1186/ s40468-020-00109-y.

* Correspondence: Gloria-ganling@ life.hkbu.edu.hk

${ }^{1}$ Department of Education Studies, Hong Kong Baptist University, 15 Baptist University Road Campus, HKSAR, China

${ }^{2}$ School of Foreign Languages, Zhongnan University of Economics and Law, 182 Nanhu Avenue, Wuhan, China

\section{Correction to: Lang Test Asia 10, 11 (2020) \\ https://doi.org/10.1186/s40468-020-00109-y}

After publication of this article (Gan and Lam, 2020), it is noticed the below two errors occurred in the article:

1) In table 2, the percentage of 'Training received' for 'Productive skills (writing/ speaking)' should be '64.7, 29.4 and 5.8' rather than '64.7, 29.4 and 5.'

2) The first sentence in the third paragraph of 'Conclusion' section is incomplete, the correct sentence should be: First of all, the university administrators and department heads should be mindful of their instructors' assessment practices, prioritize assessment training for the in-service instructors, and provide more opportunities and financial support for them to receive assessment training to keep updated in language testing and assessment.

Item 2 has been updated in the original article.

Published online: 27 September 2020

\section{Reference}

Gan, L., \& Lam, R. (2020). Understanding university English instructors' assessment training needs in the Chinese context. Language Testing in Asia, 10, 11. https://doi.org/10.1186/s40468-020-00109-y.

(c) The Author(s). 2020 Open Access This article is licensed under a Creative Commons Attribution 4.0 International License, which permits use, sharing, adaptation, distribution and reproduction in any medium or format, as long as you give appropriate credit to the original author(s) and the source, provide a link to the Creative Commons licence, and indicate if changes were made. The images or other third party material in this article are included in the article's Creative Commons licence, unless indicated otherwise in a credit line to the material. If material is not included in the article's Creative Commons licence and your intended use is not permitted by statutory regulation or exceeds the permitted use, you will need to obtain permission directly from the copyright holder. To view a copy of this licence, visit http://creativecommons.org/licenses/by/4.0/. 